\title{
DESARROLLO Y OPTIMIZACIÓN DE TÉCNICAS BASADAS EN LA FOTOCONDUCTIVIDAD PARA LA CA- RACTERIZACIÓN DE SEMICONDUCTORES CON APLICACIONES FOTOVOLTAICAS.
}

Leonardo Kopprio

leonardokopprio@gmail.com

Doctorado en Fïsica

Director: Javier Schmidt

Codirector: Roberto Arce

Lugar de realización: Grupo de Física de Semiconductores del Instituto de Física del Litoral (UNL - CONICET)

Fecha de la defensa: 3 de junio de 2019

\section{RESUMEN}

Por En esta tesis se investigan distintas técnicas de caracterización basadas en mediciones de estado estacionario relacionadas con la fotoconductividad. Específicamente, se mide la conductividad mientras al material se lo ilumina con luz monocromática de energía mayor a su banda prohibida (gap), compuesta generalmente por una iluminación espacial y/o temporalmente periódica superpuesta a una iluminación homogénea y constante de mayor intensidad. Se presenta una explicación detallada sobre la forma de implementar la fotoconductividad de estado estacionario bajo una tasa de generación uniforme (SSPC) y bajo una tasa de generación uniforme modulada en el tiempo (MPC). También se detallan las técnicas del patrón de interferencia estacionario (SSPG), el patrón de interferencia móvil (MGT), el patrón de interferencia modulado en el tiempo (MPG), el patrón de interferencia vibrante (VPG) y el patrón de interferencia oscilante (OPG). En particular, se corrige la expresión de la tasa de generación de portadores inducida por la técnica MPG presentada en la bibliografía.

Inicialmente, se presenta un formalismo general que permite analizar las densidades de corriente obtenidas con las distintas técnicas fotoconductivas en un semiconductor o aislante, independientemente de los mecanismos de transporte y recombinación de portadores del material y su grado de cristalinidad. Las expresiones de las densidades de corriente correspondientes al patrón de interferencia móvil (MGT), vibratorio (VPG) y oscilante (OPG) son presentadas por primera vez en esta Tesis. Gracias a estas expresiones, se encuentra que las densidades de corriente inducidas con las técnicas MGT y VPG en la región de bajas frecuencias permiten obtener información sobre el portador minoritario.

La medición de una corriente alterna en lugar de una corriente continua, permite la utilización de un amplificador lock-in para filtrar el ruido electrónico y así aumentar la relación señal/ruido. Trabajos previos han utilizado la corriente alterna inducida por la técnica OPG para obtener la pequeña corriente continua inducida con MGT en ausencia de campo eléctrico externo. En este trabajo se muestra mediante una simulación numérica que, para que ambas técnicas resulten equivalentes, se debe al menos 
cuadruplicar la amplitud de oscilación utilizada en los trabajos previos. Con el modulador electro-óptico del IFIS-Litoral fue imposible lograr amplitudes de oscilación tan grandes. Sin embargo, se observaron experimentalmente las mismas tendencias que fueron encontradas con la simulación numérica para pequeñas amplitudes de oscilación, validando de esta forma los resultados teóricos obtenidos. Además, se presenta una nueva forma simple de producir una corriente alterna que resulte proporcional a la corriente continua inducida por MGT. Esta consiste en modular con un chóper el haz débil en la configuración estándar de MGT, a una frecuencia suficientemente baja. Se pone a prueba esta propuesta, inicialmente mediante una simulación numérica y luego experimentalmente.

Se obtienen dos nuevos pares de fórmulas que permiten determinar la densidad de estados en las colas de banda (exponenciales) de un semiconductor amorfo, a partir de la medición de las corrientes inducidas con las técnicas SSPC, SSPG y MGT, para distintas temperaturas e intensidades de iluminación uniforme. Luego, se muestra que resulta posible estimar todos parámetros microscópicos de transporte a partir de un ajuste simultáneo de las mediciones efectuadas con SSPC y SSPG para distintas temperaturas e intensidades de iluminación. Ambos resultados fueron testeados inicialmente mediante una simulación numérica. Para poner a prueba experimental los resultados, se efectúan además mediciones del coeficiente de absorción en la región de la cola de Urbach, para determinar la pendiente de la cola de banda de valencia, y de la fotoconductividad modulada (MPC) de alta frecuencia, para estimar la densidad de estados en la región de la cola de banda de conducción y en los estados profundos. Los resultados obtenidos con estos métodos tradicionales coincidieron con los obtenidos mediante los nuevos métodos propuestos. Todas las mediciones experimentales fueron realizadas en muestras de silicio amorfo hidrogenado de calidad electrónica con contactos eléctricos coplanares de pintura de plata.

\section{ABSTRACT}

\section{Optimization and development of photoconductivity-based techniques for characterization} of semiconductors with photovoltaic applications

Different steady-state characterization techniques based on photoconductivity-related measurements are investigated. A detailed explanation is presented on how to implement the steady-state photoconductivity under a uniform generation rate (SSPC) and the photoconductivity modulated in time (MPC). The techniques of the steady-state photocarrier grating (SSPG), the moving photocarrier grating (MGT), the modulated photocarrier grating (MPG), the vibrating photocarrier grating (VPG) and the oscillating photocarrier grating (OPG), are also analyzed.

Measuring an alternating current instead of a direct current allows the use of a lock-in amplifier to filter the electronic noise and thus increase the signal-to-noise ratio. Previous works have used the alternating 
current induced by the OPG technique to obtain the small direct current produced by MGT. In this work it is shown by means of a numerical simulation that, for both techniques to be equivalent, the amplitude of oscillation used in the previous works must be at least quadruplicated. In addition, a new simple way to produce an alternating current that is proportional to the direct current induced by MGT is presented. Two new pairs of formulas are obtained that allow determining the density of states in the (exponential) band tails of an amorphous semiconductor, from measurement of the currents induced with the SSPC, SSPG and MGT techniques for different temperatures and uniform light intensities. Then, it is shown that it is possible to estimate all microscopic transport parameters from a simultaneous adjustment of the measurements made with SSPC and SSPG for different temperatures and light intensities. 